\title{
$B 8445^{\circ} \quad 20287$ \\ MASTER \\ UCRL-53138
}

\section{Geohydrology of the Climax Stock Granite and Surrounding Rock Formations, NTS}

W. A. Murray

May 1981

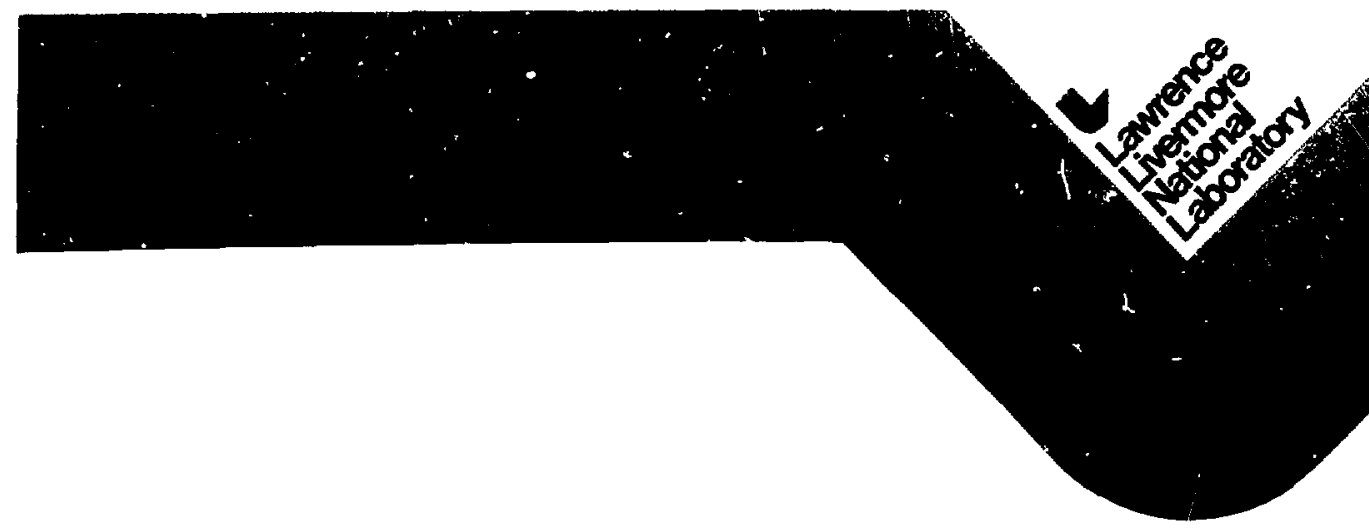


UCRL -53138

Distribution Catgory UC-70

\title{
Geohydrology of the Climax Stock Granite and Surrounding Rock Formations, NTS
}

\author{
W. A. Murray
}

Manuscript date: May 1981

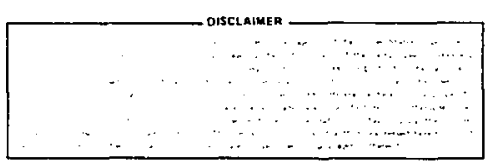

LAWRENCE LIVERMORE LABORATORY

University of California - Livermore. California • 94550 


\section{CONTENTS}

Abstract

Introduction

Geography and Geology

Physiography

Geologic Setting . . . . . . . . . . . . . . . 1i

Geohydrology . . . . . . . . . . . . . . . . 26

Regional Flow-Southern Nevada . . . . . . . . . . 26

NTS Flow Patterns . . . . . . . . . . . . . . . . . 26

Groundwater in the Area Surrounding the Climax Stock . . . . . 30

Groundwater in the Climax Stock . . . . . . . . . . . . 37

Inferring the Water Table Location . . . . . . . . . . 42

Conc lusions

Acknowledgments . . . . . . . . . . . . . . . . 46

References 


\section{ABSTRACT}

The location of the water table and the degree of saturation of the granitic rocks in the $\mathrm{Cl}$ imax stock are presently unknown. Based on existing knowledge and an extrapolation of available geohydrologic data, it appears that the water table may lie at about 1100-1200 m above mean sea level (MSL) in the northeastern part of the stock and at about 800-900 $\mathrm{m}$ in the southwest. A driliing progran would be required to establish these levels precisely. The degree of saturation at a given underground elevation may be approximated by a detailed inventory of seeps at that level. Hore precise determination of degree of saturation will require a water budget.

\section{INTRODUCTION}

The Nevada Test Site (NTS) is a U.S. Department of Energy facility primarily used for nuclear weapons testing. The Climax stock is a granitic rock mass that nas intruded through Paleozoic sedimentary rocks and Tertiary volcanics at the northern end of NTS, where it crops out over an area of about $4 \mathrm{~km}^{2}$ (see Fig. 1).

Initial exploration of the climax stock was conducted in the late 1950s to determine the suitability of the rock mass for nuclear tests and to estimate the water content of the rock. Rock composition and properties (including permeability) were determined from core sample tests and in situ field tests. Subsequent]y, two shafts were excavated in the Climax stock for nuclear tests, the "Tiny Tot" and the "pile Driver" shafts (see Fig. 2). Extensive horizontal tunnel complexes are associated with the Pile Oriver shaft. At the 250-m depth level, there are drifts from the "Hard Hat" event; and at the 420-m depth level, drifts from the Pile Oriver event (see Fig. 3 ). 


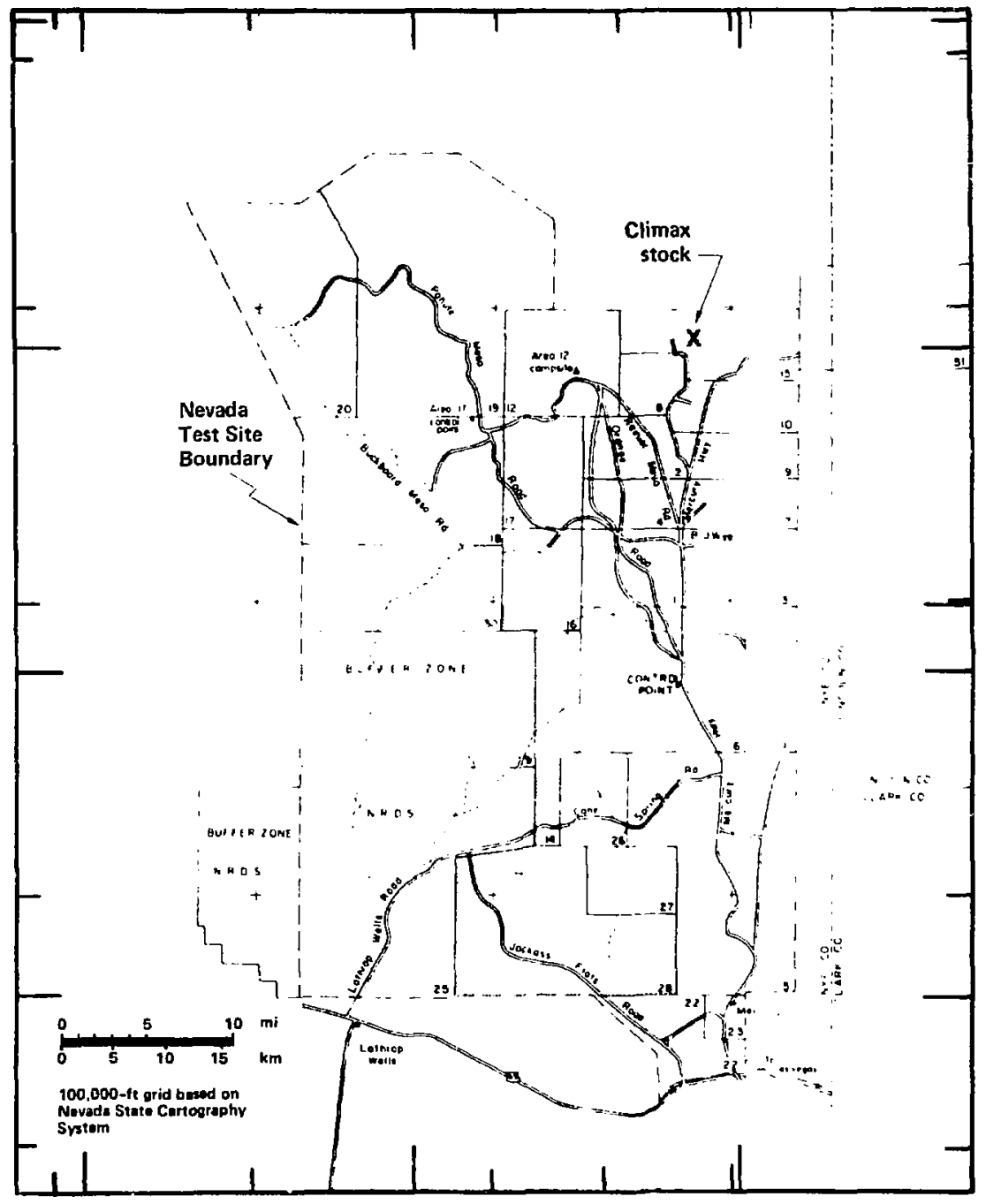

FIG. 1. Index map showing location of Climax stock in Area 15, NTS (from Maldonado, 1977). 


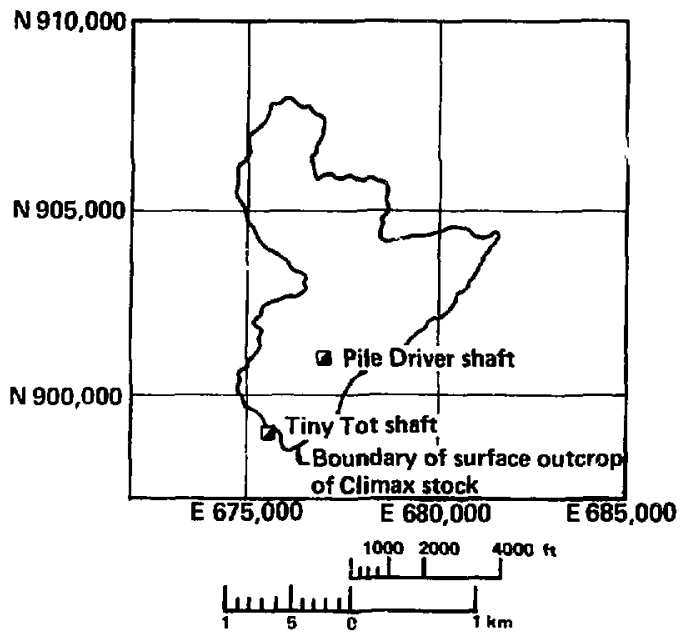

FIG. 2. Shaft locations in the Climax stock. 


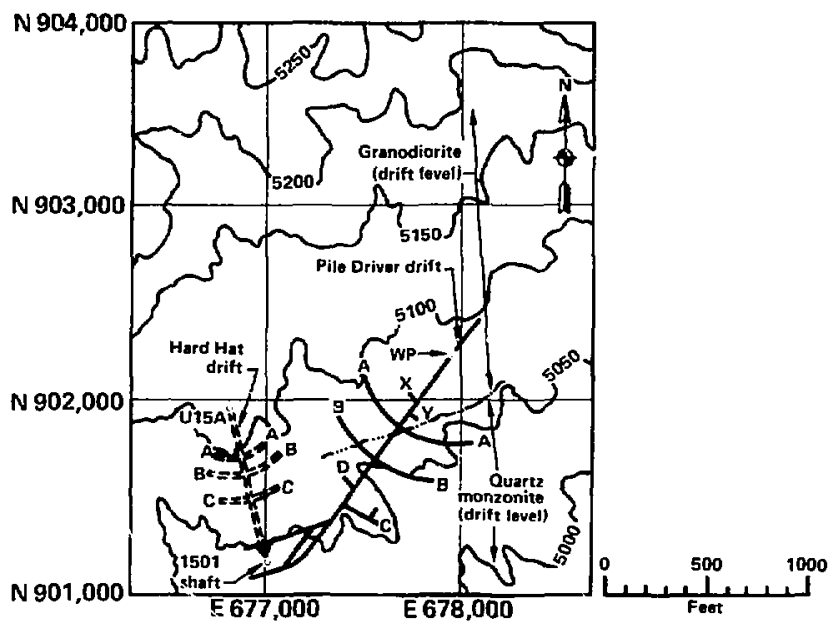

FIG. 3. Pile Driver and Hard Hat tunnel complexes. Contours show elevation in feet above sea level (from Borg, 1970). 
The existing underground facilities have enabled a detailed physical description of the granitic mass and have provided ready access to the climax granite at a considerable depth. The facilities are, therefore, ideal for in situ tests. Geologic storage of spent reactor fuel (the Spent Fuel Test-Climax; Ramspott, et al., 1979) is being generically tested in newly mined drifts adjacent to the older drifts at the $420-m$ depth level of the Pile Driver shaft. Also, the recently initiated Radionuclide Migration Test (Isherwood, et al., 1980) is being conducted in an existing drift from the Pile Driver event. The layout of these tests relative to the preexisting Pile Driver tunnel complex is shown in Fig. 4 .

As an adjunct to the Spent Fuel Test, it has been proposed to establish a "Rock Mechanics Test Facility" in the Climax granite. This facility would be used to define relevant rock mechanics tests for a hard-rock repository and would test Ci imax stock granite on site. However, tine suitability of the climax granite site for rock mechanics testing has been questioned because the present working level apparently lies above the reyional water tabie. Specifically the following question has been asked:

Which rock mechanics tests can be conducted in a partially saturated medium that will be generilly applicable to the design of nard-rock repositories in saturated rock?

The answer to this question is addressed in a recent report by Heuze (1981). However, the fact that the present working level at $420 \mathrm{~m}$ below the ground surface is generally accepted to be above the regional water table has raised two quest:ons:

Where is the water table within the Climax stack?

and

What is the degree of saturation of tine rock mass at the present working ievel? 


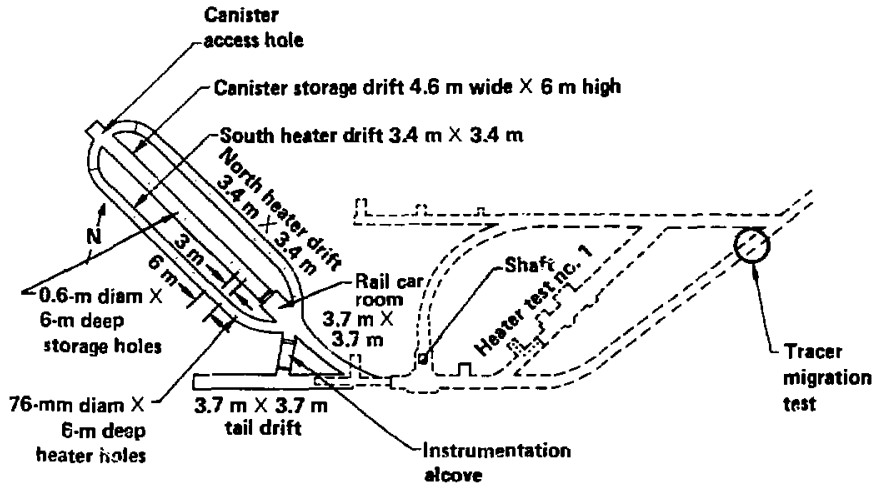

- - Existing workings Now construction

FIG. 4. Layout of the Spent Fuel Test facility and adjacent workings (from Ramspott et al., 1979). 
The question of water table location within the Climax stock has not yet been satisfactorily answered. A water table may not occur in the moderately fracturef rock mass the way it does in an alluvial deposit. If the fractures are not well interconnected, only isolated pockets of water may occur at different elevations. However, this report assumes that the fractures in the rock mass are sufficiently interconnected to permit a regional water table aquifer (in addition to local pockets of perched water)and to transmit water inrough the $\mathrm{Climax}$ stock.

In an attempt to answer the latter two questions above, this report:

- Sumarizes the existing knowledge of geology and hydrology of the Climax stock and surrounding rock formations.

- Extrapolates existing data (from regional hydrology, NTS-scale hydrology, and local structural geology) to deduce the location of the water table within the Climax stock, the source of water at the working level of $420 \mathrm{~m} \mathrm{depth}$, and the possible degree of saturation in the rocks of the $\mathrm{Cl}$ imax stock.

\section{GEOGRAPHY AND GEOLOGY}

PHYSIOGRAPHY

The Nevada Test Site in Nye County covers about $3600 \mathrm{~km}^{2}$ (see Fig. 5) and lies in the south-central part of the Great Basin section of the Basin and Range physiographic province. Yucca Flat, Frenchmen Flat, and Jackass Flats are the major intermontane valleys within NTS, and their fluors range in elevation from 850-1200 $\mathrm{m}$ above MSL. Pahute and Rainier Mesas in the northwestern portion of NTS have the highest elevation, over $2100 \mathrm{~m}$. There is an overall ground-surface slope to the southwest across the site towards Death Valley, which has a minimum elevation of $85 \mathrm{~m}$ below MSL (Borg et al., 1976). 

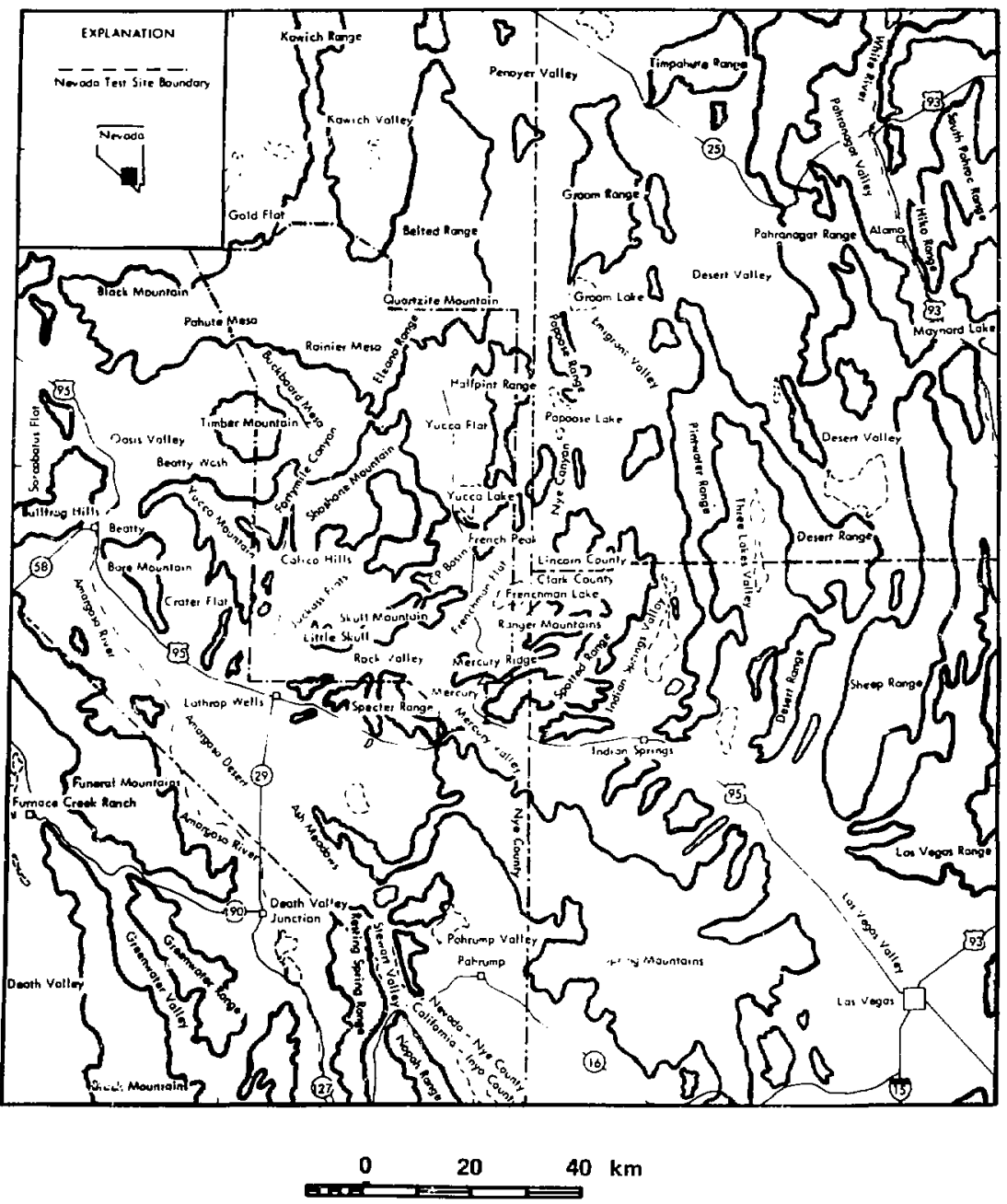

FIG. 5. Index map of Nevado Tesi site and vicinity (from Winograd and Thordarson, 1975). 
Over the 6 ilimax stock outcrop the ground-surface elevation varies from about $1500 \mathrm{~m}(4900 \mathrm{ft})$ at the southern edge to about $1800 \mathrm{~m}$ $(5900 \mathrm{ft}$ ) in the north (see Fig. 6). The Climax stock is situated at the north end of Yucca Flat (as can be see n Fig. 8) and elevations rise steeply to the north and west of the stuk. There is a large uplani area to the north and west of the Climax stock that corsists of Pahuté ar $J$ Rainier Mesas, and tlue Eleana and Belted Ranges. Elevations in these uplands exceed $2100 \mathrm{~m}$. Two orainage areas, watershed $A$ and watershed $B$, have been delineated on Fig. 6, which shows the Climax stock lying almost totally within tie smaller draindge area, watershed A. However, a small portion of the southern tip of the stock lies in the :arger drainage area, watershed $B$, shich contains watershed $A$.

The climate of the tost site area is arid, and the vegetaticn is typical of that in desert regions. The average annual precipitation in the valleys ranges from 80-150 mm, and averages less than $250 \mathrm{~mm}$ on most ridges and mesas (winograd and Thordarson, 1975). Based on an isohyetal map presented by Winograd and Thordarson, average annual precipitation over the Climax stock area may vary from 150-200 mm. This includes the entire area shown in Fig. 6. The average annual precipitation at the NTS Experimental Farm, $3 \mathrm{~km}$ SE of the Climax stock, is about $190 \mathrm{~mm}$ for the 14-yr period from 1965 through 1978. Monthly variations in precipitation, temperature, and relative humility as recorded at the Experimental Farm are shown in Fig. 7. As can b? seen, there are two precipitation peaks, one in February and the other in August.

Several washes drain watershed $A$ directly across the Clinax siock outcrop. This provides the opportunity for direct infi?tration into the stock through the permeable, coarse-grained, unconsolidated material providing a thin cover over the intact granitic rocks. The relatively large Oak Spring wash drains most of watershed $B$ past the southern edge of the stock into the alluvium of Yucca Flat. Water carried by this wash can infiltrate alluvium overlying the intruded rozk, subsequently reacning the granitic mass at a siightly greater depth.

The amount of total precipitation to eventually recharge the groundwater system by deep percolation depends on the amount of evapotranspiration and surface runoff. Because of the arid cliricite at 


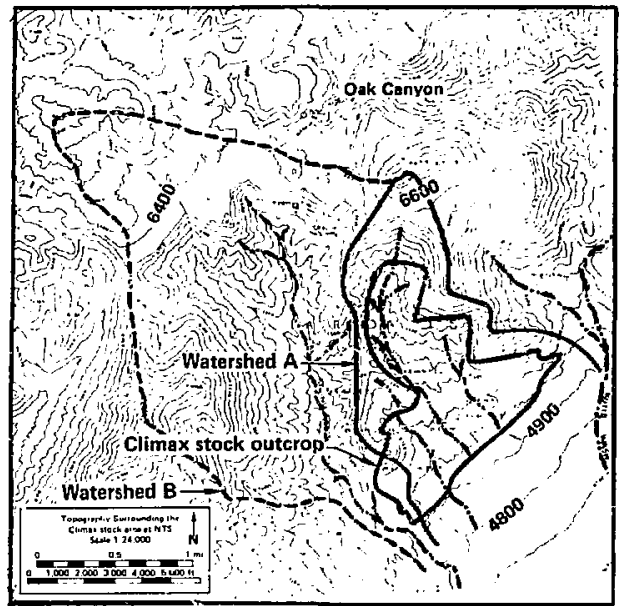

FIG. 6. Topographic relief and watershed delineation in the vicinity of the Climax stock. Contours show elevation in feet above sea level; scale: I in. $=5000 \mathrm{ft}$ (contours redrawn from USGS Quadrangle Maps). 


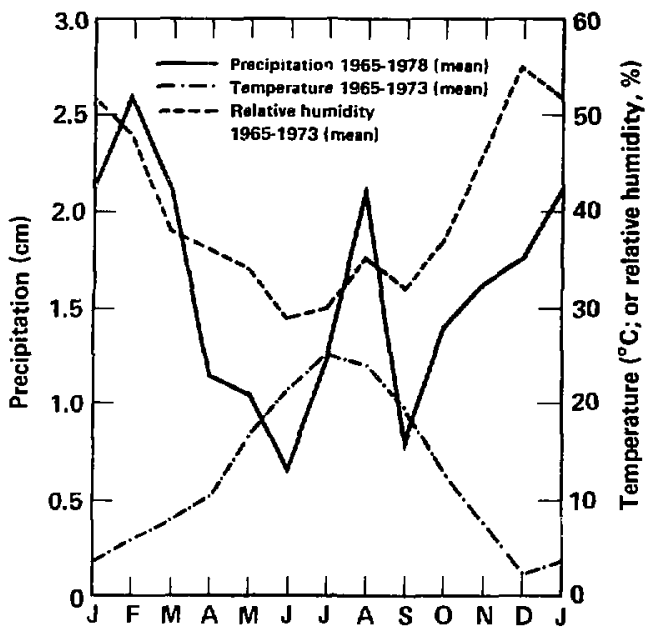

FIG. 7. Average monshly precipitation, temperature, ind relative humidity at NTS Experimental Farm, about $3 \mathrm{~km}$ southeast of Climax stock (data from DOE, 1980). 
NTS, evapotranspiration is high. Borg et al. (1976) conclude it is reasonable to assume that annual precipitation is exceeded by annual evapotranspiration in the valleys of NTS. However, precipitation may exceed evapotranspiration in upland areas for limited periods of time, especially in the winter months. Furthermore, snowmelt from dpland accumulations probably results in infiltration and recharge of the ground water at higher elevations. This is likely in some of the ared surrounding the $\mathrm{Cl}$ imax stock.

\section{GEOLOGIC SETTING}

The rocks surrounding the $\mathrm{Climax}$ stock at the ground surface are shown in Figs. 8 and 9. Vertical sections as depicted in Fig. 1.3, are shown in Figs. 11 a.d 12. Paleozoic sedimentary rocks complete?y bound the srock on the west. The Paleozoics are overlain by Tertiary volcanic tisf to the south and, to a small degree, to the east. The entire NTS region is geologically complex. It lies within the miogeosynclinal belt of the Cordilleran geosyncline, in which $11,300 \mathrm{~m}$ of marine carbonates and clastics accumulated during the Precanbrian and Paleozoic eras. Except for smal! intrusive masses (e.g., the Climax stock) no rocks of Mesozoic age are found in the area. The region also lies within a Tertiary volcanic province in which extrusive volcanic rocks are locally more that $4000 \mathrm{~m}$ thick (Winograd and Thordarson, 1975). In the Climax area, volcanics form layers over the Paleozoic rocks a few hundred meters in thickness. Quaternary alluvium fills most of the valleys and is found to be about $100 \mathrm{~m}$ thick southeast of the $\mathrm{Climax}$ stock.

The Climax stock is an intrusive granitic mass of Cretaceous age consisting primarily of granodiorite and porphyritic quartz monzonite. The stock outcrops over an area of $4 \mathrm{~km}^{2}$ at the northern end of Yucca Flat (see Fig. 8), and intrudes a sequence of sedimentary rocks of Paleozoic age (mainly limestone, dolomite, and shale). This sedimentary sequence is overlain by Tertiary pyroclastic rocks of the 0ak Spring Formation, consisting of tuff, welded tuff and breccia (A)lingham and Zietz, 1961). The detailed outcrop pattern and adjacent rock types are shown in Fig. 9. 


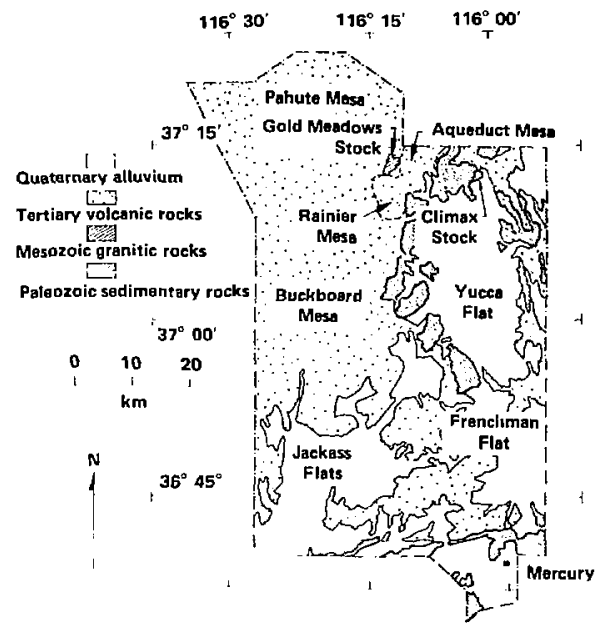

FIG. 8. Principal rock types and test areas at Nevada Test Site (modified from Barnes, et al, ?963). 
[4.3 Alluvium (quaternary)

ITd Volcanic tuff, undifferenriated (tertiary)

[rigs Quartz monzonite, climax stock (cretaceous)

Granodiorite, climax stock (cretaceous)

A Limestone, dolomite, shale, and quartzite, undivided (paleozoic)

Contact - dashed where approximately lacated

-_-_.. Fault - dashed where approximately lacated. Dotted where concealed. Bar and ball on downthrown side.

- Shaft

in se O Drill hole - showing total depth :

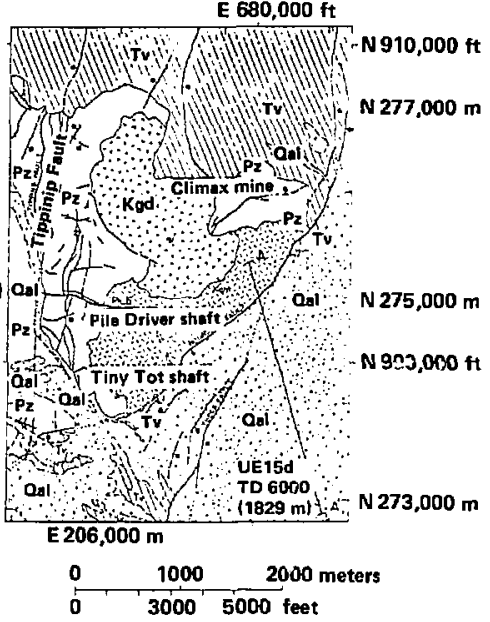

FIG. 9. Geologic map of Climax stock (modified from Barnes, et al, 1963). 


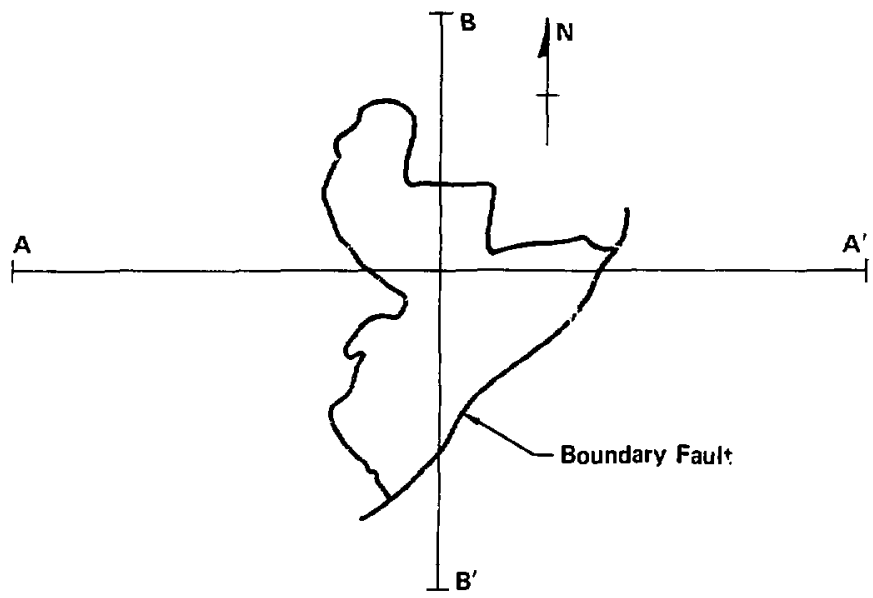

FIG. 10. Locations of vertical sections through the climax stock. 


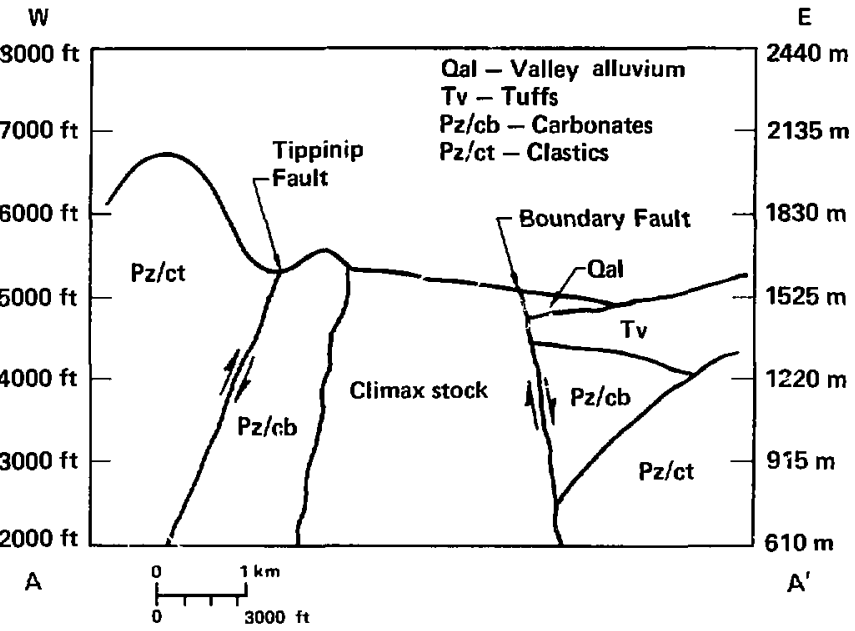

FIG. 11. Geologic section through Climax stock, east-west (modified from Houser and Poole, 1960). 


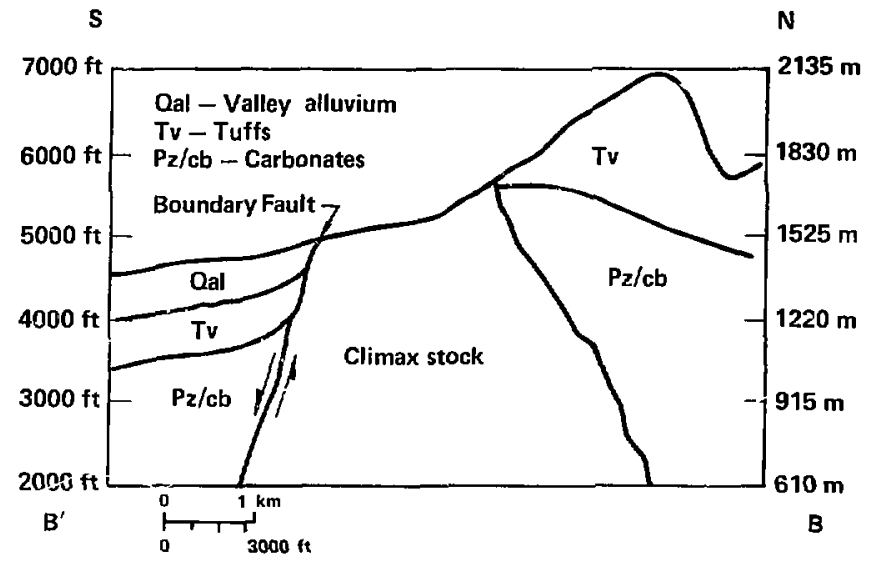

FIG. 12. Geologic section through Climax stock, north-south (modified from Houser and Poole, 1960). 
Allingham and Zietz (1961) conducted a three-dimensional analysis of a detailed aeromagnetic survey. They established that the stock is shaped like a truncated cone, whose diameter increases from about $2 \mathrm{~km}$ at the surface to at least $10 \mathrm{~km}$ near sea level. Their computations also show that the intrusion is at least $4600 \mathrm{~m}$ thick. Figure 13 shows the best fit of the computed magnetic curve to the observed east-west profile across the igneous outcrop. The general size and shape of the Clima: intrusive are also shown.

Maldonado (1977) has summarized the geology and physical properties of the Climax and portions of his summary are reproduced below. Three major faults are found in the vicinity of the stock (Fig. 9), the ippinip Fault, the Boundary Fault and the Yucca Fault. The Tippinip Fault is located west of the Climax stock ard trends north-northeast, displacing the Palenzoic sedimentary rocks, the west block down relative to the east block. The Tippinip Fault intersects the projection of the Boundary Fault southwest of the stock. The Boundary Fauls, which trends northeast, is located on the southeast side of the stock, placing the stock in fault contact with alluvium and tuff. In the southern part of the stock, the dip of the fault has been measured at $75^{\circ} \mathrm{SE}$; the: southeastern block is displaced dowrward relative to the northwest block. The Yucca Fault, the principal eipused structural feature within the Yucca Flat area, is located south of the Climax stock. It trends northward through the middle of Yucca Flat and northeastward near the Climax stock, displacing the east block downward relative to the west block. The Yucca Fault possibly joins the Boundary Fault just south or southeast of the stock.

The granitic rock of the climax stock is jointed and contains numerous shear and fault zones where it has been mapped both on the surface and in underground workings (Ege and Davis, 1965). There are three predominant joint trends in the stock located approximately:

- NW and low angle

- NW and high angle

- NE and vertical or dipping at a high angle to the SE. 


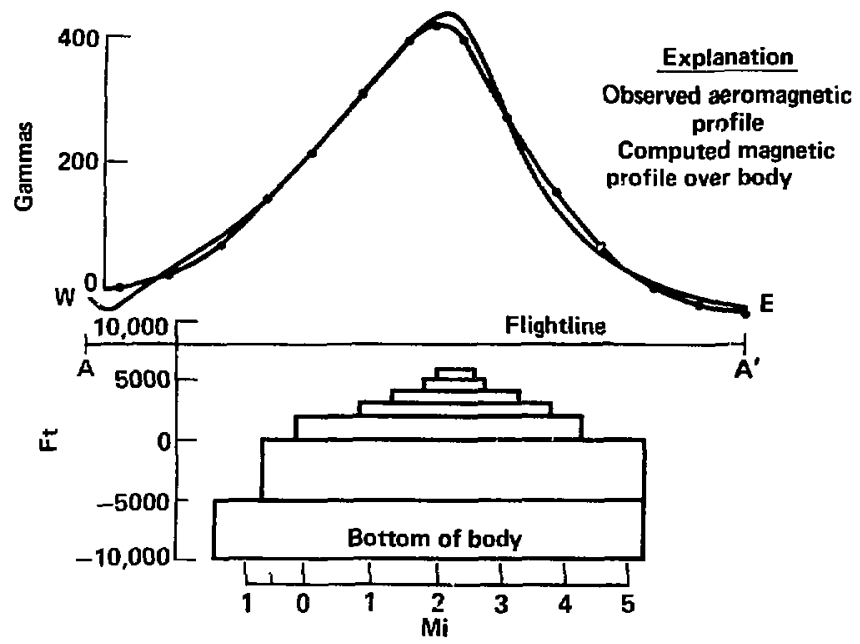

FIG. 13. Aoproximation of Climax stock shape and depth (Allingham and Zietz, 1961). 
Joints in outcrops are weathered and open, but are cormonly filled in the subsurface and, in some instances, completely healed with chlorite, quartz, secondary feldspar, clay minerals, calcareous clay, calcite, and sulfide minerals. The nearly vertical fractures tend to he more open than the low-angle ones.

Faults, joints, and shear zones have been mapped for both the Hard Hat and Pile Driver tunnel complexes. Of particular interest are the shear zones. Fiçures 14 and 15 show mapped locations of shear zones in the Hard Hat and Pile Driver tunnel complexes. Shear zones are a series of closely spaced fractures that define a zone of crushed rock. The rock is crushed to granular size in places, and the zone is righly porous. The porosity of the intact granite has an average value of about $0.6 \%$. However, the porosity of the shear zones may be as nigh as 20 or $30 \%$. Two samples of shear-zone crushed rock were collected and analyzed in the laboratory for grain size distribution. In each case, about $64 \%$ (by weight) of the total sample consisted of granitic rock fragments larger than $11 / 4 \mathrm{~cm}$. The remainder of each sample (about $36 \%$ by weight) was subjected to a standard sieve analysis. The results of the sieve analys is are shown in Fig. 16. It can be seen that there is very little fine-grained material. Both silt- ard clay-sized fractions are essentially nonexistent. It is also interesting to note that the grain size distribution is very similar in both of the shear zones. The two zones are located about $40 \mathrm{~m}$ apart in the Pile Driver tunnel. The shear zones in the stock, especially the larger, more extensive ones, are probably very significant hydrologically. This will be discussed further in the geohydrology section of this report.

When the drifts were excavated for the Spent Fuel Test, (Ramspott et al., 1979) many shear zones were encountered, and they appear to occur extensively throughout the stock. Also encountered during this excavation was a racher large fault. This fault has a $30-\mathrm{cm}-w i d e$ clay gouge plus a wider zone of fractured and crushed rock. Evidence indicates movement in excess of several meters has occurred along the fault. The fault strikes about $N 50^{\circ} \mathrm{E}$, dipping about $65^{\mathrm{G}}$ to the southeast. Figure 17 shows its approximate surface location. The fault probably extends completely through the stock and could hence form a significant hydrologic barrier, due to the associated clay gouge. Figure 18 shows the location of the fault in the Spent Fuel Test workings. 


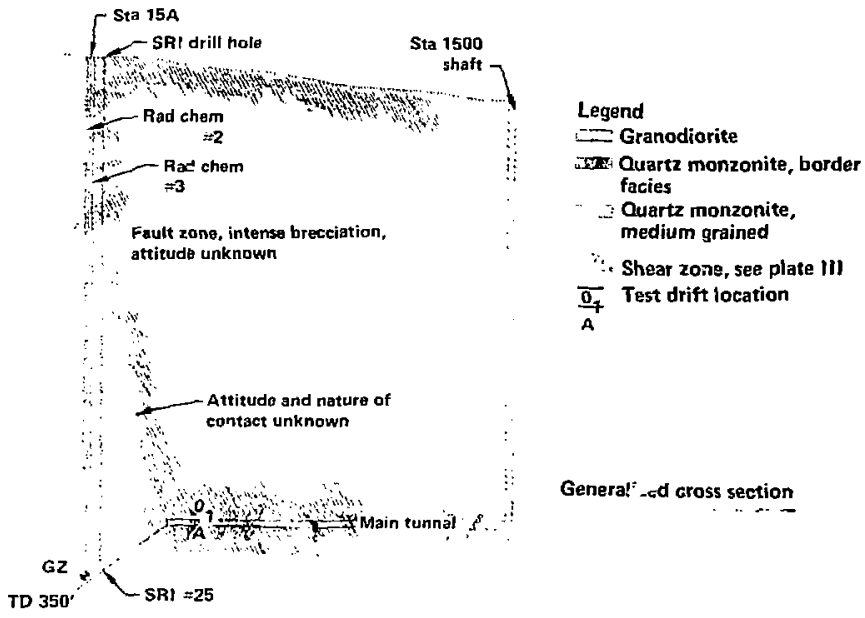

FIG. 14. Locations of shear zones-vertical section (Hard Hat workings). 


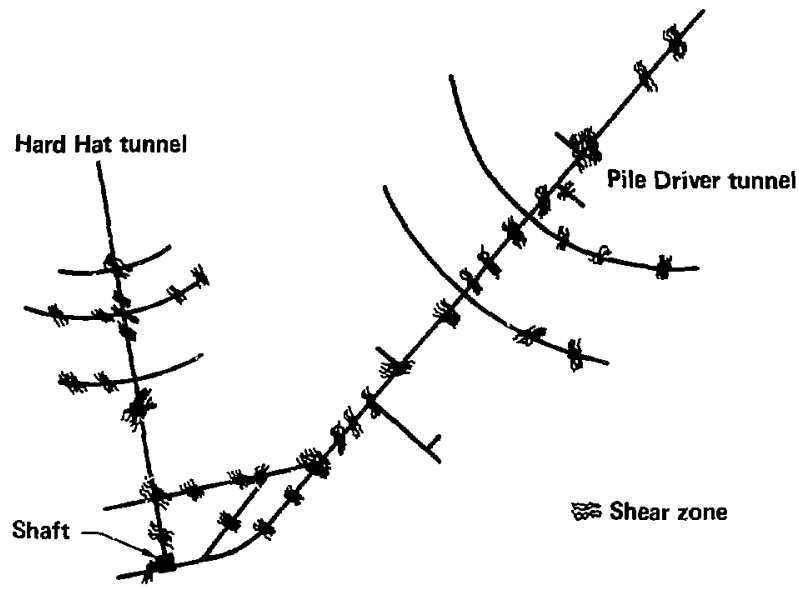

FIG. 15. Locations of mapped shear zones in underground workings (p lan view). 


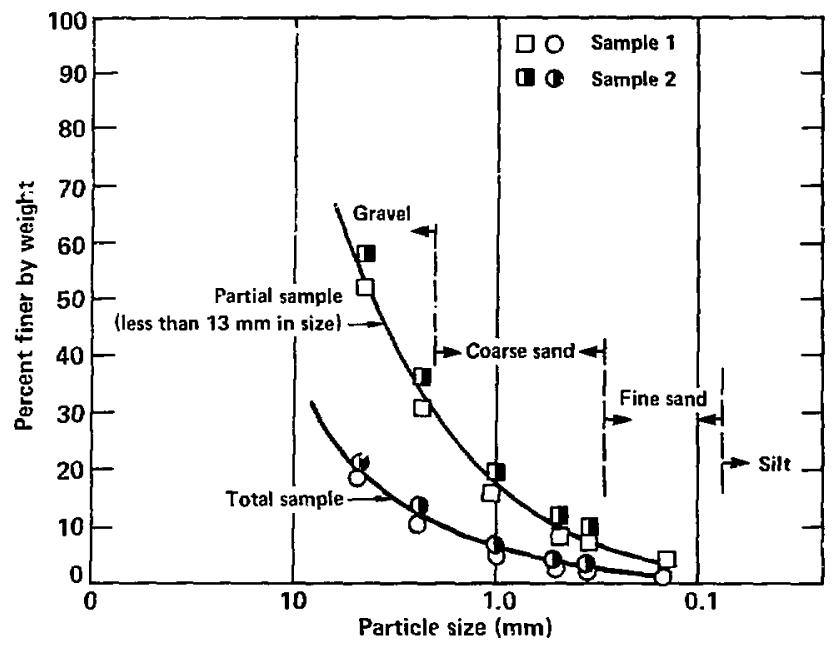

FIG. 16. Particle-size distribution of shear zone material. 


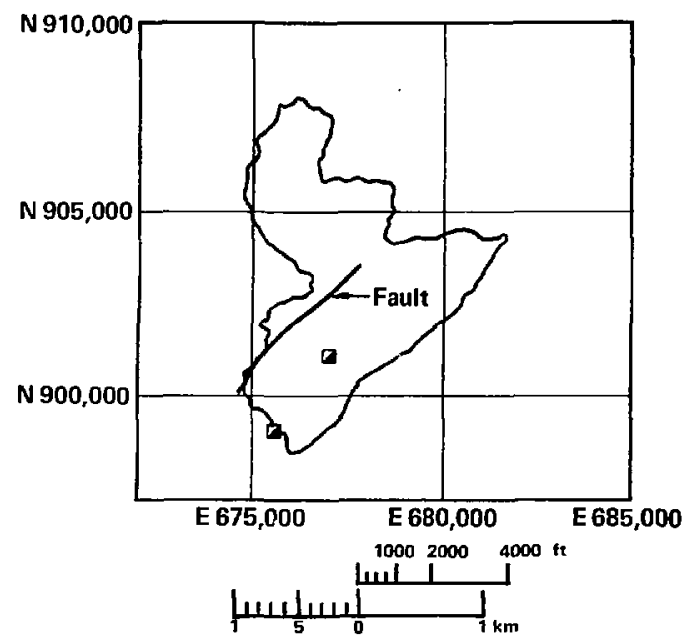

FIG. 17. Climax stock showing inferred fauit location (modified from Wilder, 1979). 


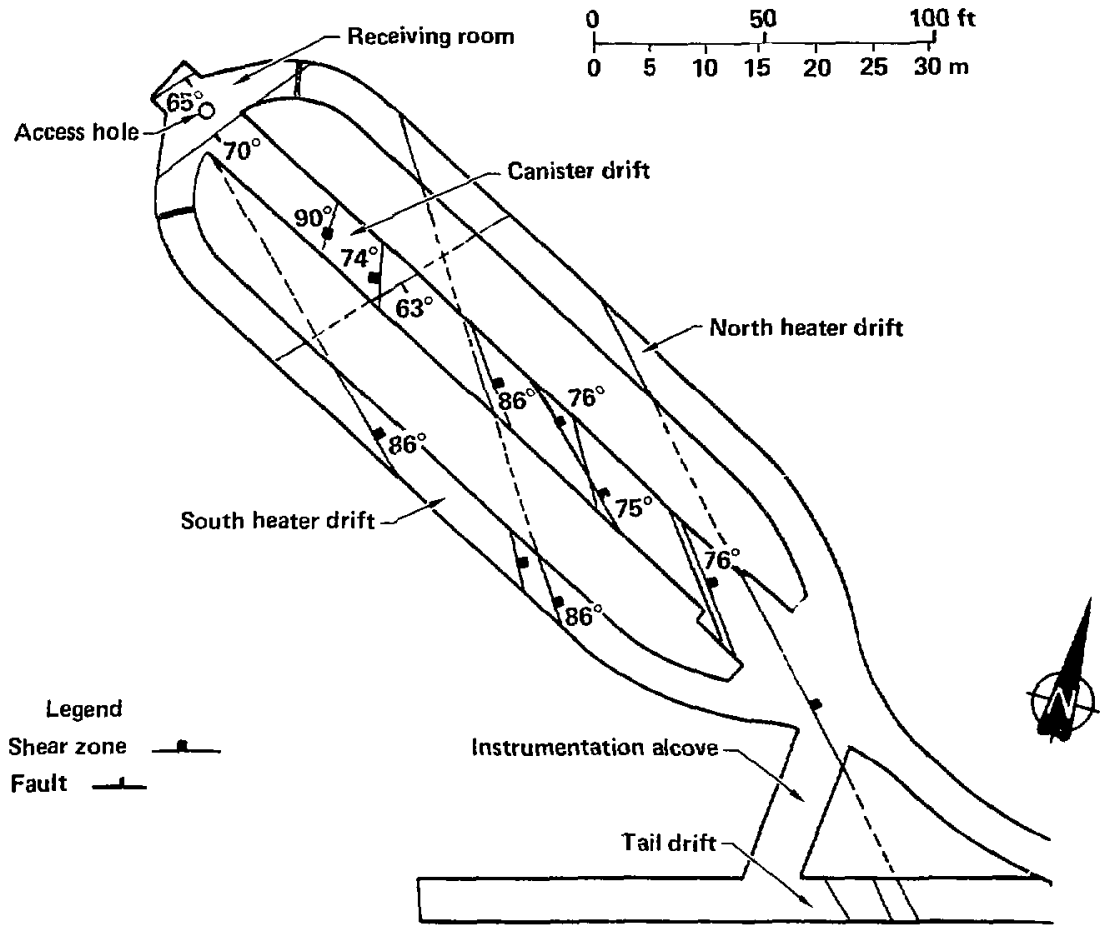

FIG. 18. Fault and shear zone locations in the Spent Fuel Test workings relative to major geologic features (modified from Wilder and Patrick, 1980). 
GEOHYDROLOGY

REGIONAL FLOW--SOUTHERN NEVADA

Mifflin (1968) conducted a study to delineate the groundwater flow systems in Nevada. Several techniques for flow system delineation were investigated, including water budget, chemistry, and temperature interpretation. Although Mifflin recognized the potential value of groundwater temperature as an irdication of flow system configuration, he did not fully explore it. He postulated, however, that if most thermal groundwater in Nevada is not generated by shallow, high-temperature bodies of rock, the fluid potential of thermal water may indicate the general direction in which deeply circulated groundwater flows. The potentiometric map in Fig. 19 was produced by contouring the fluid potentials of known groundwater occurrences equal to or greater than $80^{\circ} \mathrm{F}$. This map may indicate fluid potentials in deeply circulating interbasin flow. The location of NTS and the Climax stock is also shown on the map. It can be seen that the general groundwater flow direction is north to south across NTS and that the fluid potential level varies from about $1200 \mathrm{~m}(4000 \mathrm{ft})$ above MSL in the north to about $760 \mathrm{~m}(2500 \mathrm{ft})$ in the south. At the Climax stock this deeply circulating interbasin flow potential is about $1100 \mathrm{~m}(3600 \mathrm{ft})$.

\section{NTS FLOW PATTERNS}

The geohydrology of the Nevada Test Site has been reported by Winograd and Thordarson (1975) and summarized by Borg et al. (1976). Test drilling at the site has proven that at least five, and probably seven, intermontane basins are hydraulically connected by groundwater movement through the Pale: zoic carbonate strata. The carbonate aquifers of the miogeosyncline are compartmentalized by major structural features that form prominent hydraulic barriers between or within the intermontane 


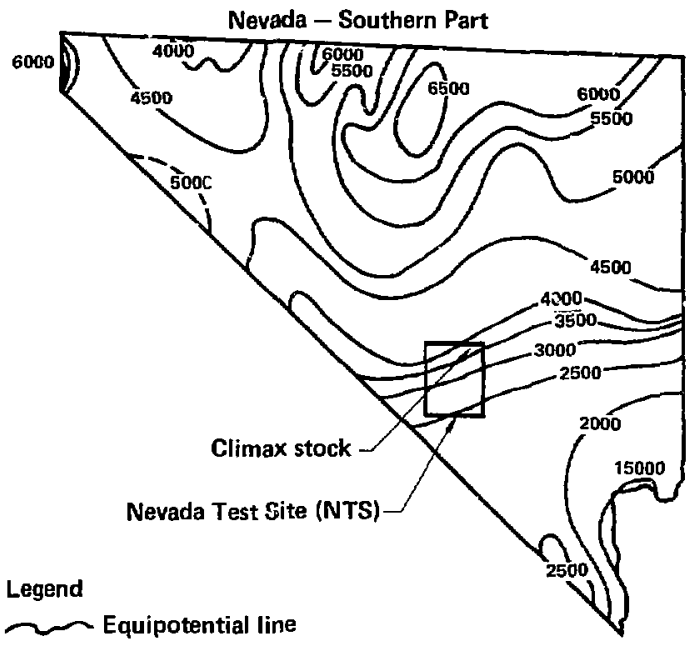

FIG. 19. Equipotential map of groundwater equal to or greater than $80^{\circ} \mathrm{F}$ (from Mifflin, 1968). 
basins. Hence, the aquifer flow systems are very complex on a local scale. Winograd and Thordarson have grouped the stratigraphic units of NTS into 10 hydrogeologic units. Of these, the lower carbonate aquifer, the lower clastic aquitard, and the upper clastic aquitard have a major influence on groundwater levels around the climax stock. The valley fill aquifer, tuff aquifer, and tuff aquitard play more minor roles. The Paleozoic carbonates have fracture transmissibilities ranging from $12-12000 \mathrm{~m}^{2} /$ day $(1,000-1,000,000 \mathrm{ga} 1 / \mathrm{day} / \mathrm{ft})$. The transmissibilities of the clastic rocks are, on the other hand, extremely low (less than 12 $\mathrm{m}^{2} /$ day). Therefore, structural juxtaposition of che clastic and carbonate rocks should result in prominent hydraulic discontinuities (Winograd and Thordarson, 1968). Such phenomena occur near the $\mathrm{Climax}$ stock.

Within the Test Site, the general direction of groundwater movement is north to south, from areas of recharge in the uplands at the northern end of NTS, through the carbonate rocks beneath Yucca and Frenchman Flats, under Mercury Valley to discharge areas (springs) in the Amargosa Desert south of NTS (see Fig. 20). In a qualitative sense, groundwater levels and flow directions compare favorably with those of Fig. 19. As would be expected, local exceptions to the general north-to-south direction of flow abound. In the volcanic tuffs of Pahute Mesa the flow is more nearly to the west within NTS boundaries, and in Yucca $F$ lat (where the carbonate rocks are bounded on the east and west by clastic rock aquitards) a north-to-south trough cuts into the regiorial flow pattern. The structural geology that causes this trough aljo I is a direct bearing on groundwater levels in and around the $\mathrm{Climax}$ stock.

Figure 20 also indicates a probable groundwater divide running rorth to south between the Climax stock and Pahute Mesa. Borg st al. (1976) suggest that this divide is fairly extensive, running completely through NTS from north to south. 


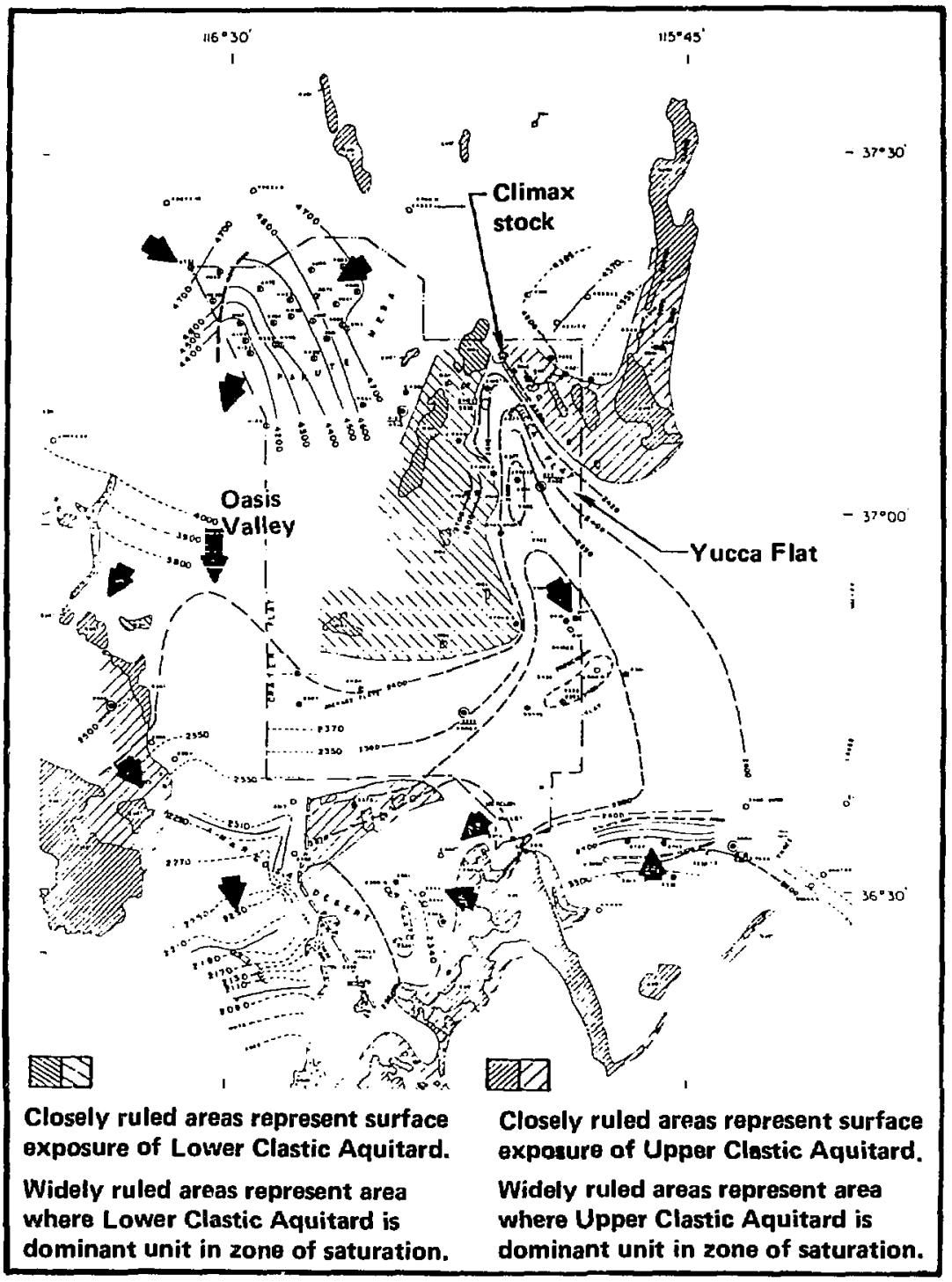

FIG. 20. Potentiometric contours (Nevada Test Site and vicinity) are dashed where inferred and given in feet above MSL (from Winograd and Thordarson, 1968). 
The Climax stock is bounded by Yucca Flat to the south, whose potentiometric levels are fairly well defined; Eleana Range and Quartzite Mountain to the west, for which measured potentiometric levels are nonexistent; and Belted Range to the north and Halfpint Range to the east, in which few potentiometric levels have been measured. These measured levels are the basis for the contours drawn in Fig. 20. It should be nuted, however, that most of the contour lines in the vicinity of the Climax stock are shown dashed, meaning they are inferred. Hence, there are insufficient data to establish these contours with certainty. This simply reflects the paucity of measured water levels for such a geologically complex area. However, groundwater levels are certainly high to the north of the stock, probably as high as 1300-1350 m (4250-4400 ft) above MSL, and low to the south in Yucca Flat, around $750 \mathrm{~m}$ (2500 ft).

Beneath northern Yucca Flat, the lower and upper clastic aquitards apparently isolate the lower carbonate aquifer from adjacent valleys. Thus, any interbas in flow of groundwater into the lower carbonate rocks beneath Yucca Flat would have to pass through the clastics. However, on the west, the upper clastic rocks are underlain by the lower carbonates, while on the east, the lower clastics are underlain by Precambrian clastics and crystalline basement rocks. Therefore, the upper clastic rocks do not necessarily retard movement of groundwater into Yucca flat from the west or northwest where movement could occur through carbonate aquifers hundreds of meters below ground surface. This, of course, depends on the nature of the Tippinip thrust fault, which could, at least partic' $7 y$, isolate the lower carbonates to the west (Winograd and Thord srson, 1975).

In northeastern Yucca Flat, the lower clastics form an effective hydraulic barrier, as is shown in Figs. 21 and 22. The extremely steep gradient from the lower clastics into the carbonate rocks of Yucca flat is indicative of the low transmissibility of the clastic rocks (Fig. 22). However, it is also possible that the large drop in potentiometric level could be caused by Yucca Fault acting as a hydraulic barrier. 


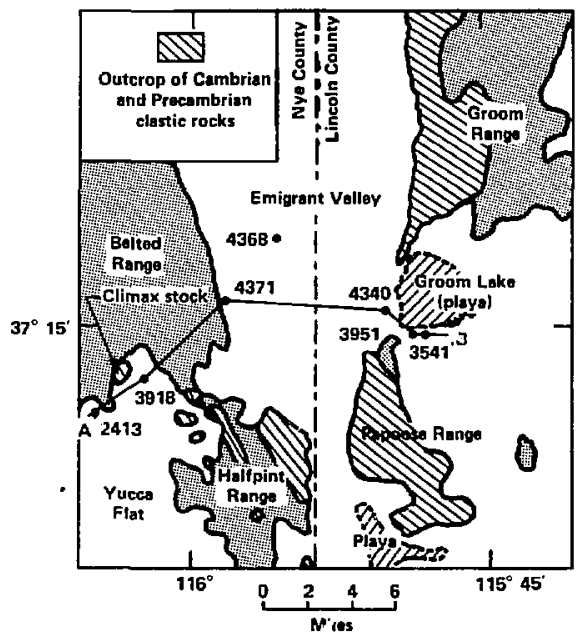

FIG. 21. Plan location of vertical section $A B$ shown in $F$ ig. 22; numbers represent water levels in feet above MSL (from Winograd and Thordarson, 1968). 


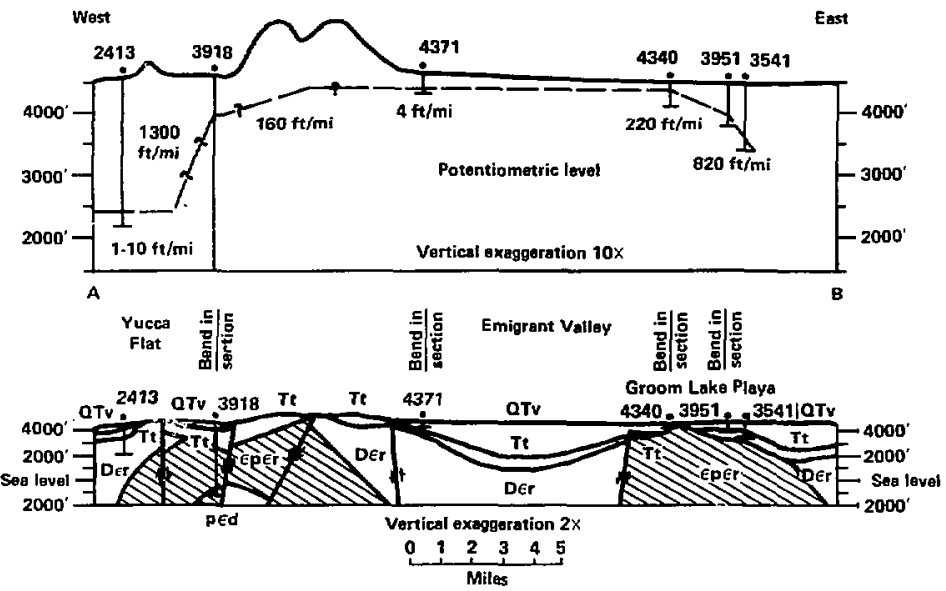

FIG. 22. Geologic and hydrologic cross section (location shown in Fig. 21): Qtv, Quaternary and Tertiary valley fill; Tt, Tertiary tuff; $\mathrm{OCr}$, Devonian to Cambrian carbonate rocks; CPCr, Lower Cambrian to Precambrian clastic rocks; pCd, Precambrian dolomite (from Winograd and Thordarson, 1968). 
Figures 23 and 24 show the geology near the Climax stock at the 730-m (2400-ft) elevation and two geologic sections running east to west, one through the Climax stock, and the cther just south of the stock. It is logical to assume from these geologic interpretations that groundwater flows from regions of high potential north of the $\mathrm{Climax}$ stock, around the stock to the west, through the lower carbonate aquifer into Yucca flat. However, flow around the stock to the east is apparently blocked by the lower clastic aquitard. It is not known to what extent north-to-south trending fault lines inhibit lateral flow from the west into Yucca flat, or enhance flow from north to south through the lower clastic aquifer.

Figure 25 shows the location of test wells near the 61 imax stock and their reported water levels. Also shown are water table contours from the USGS map of Yucca Flat (1976) and the regional, deep-circulating water level contours from Mifflin (i968). The potentiometric levels in the Paleozoic rocks and in Quaternary and Tertiary units are also given (Winograd and Thordarson, 1975). The relatively high 915-m water table contour is largely inferred, based on a few water levels in wells that penetrate the clastic rocks. Because clastic rocks do not exist south of the Climax stock (they lie in bands that run in a north-to-south direction both east and west of the stock), it is thought that this $915-\mathrm{m}$ contour may not close south of the stock as shown. This contour may, instead, intersect the stock or encircle it to the north, remaining in the clastic rocks to the east and west. Water levels are expected to remain lower in the carbonate rocks that abut the stock to the south and southwest. Also, since the $1189-\mathrm{m}$ contour is based on a single borehole water level, its direction may tend more to the east of the stock rather than intersecting it as shown. Water level measurements do, however indicate higher potentiometric levels in the Quaternary alluvium and Tertiary volcanics than those of the lower carbonate aquifer. Hence, in the northern Yucca Flat area, water flows vertically downward through the Quaternary alluvium and Tertiary volcanics into the lower carbonate aquifer. This indicates that the Climax stock is in a recharge area for the lower carbonate aquifer. 


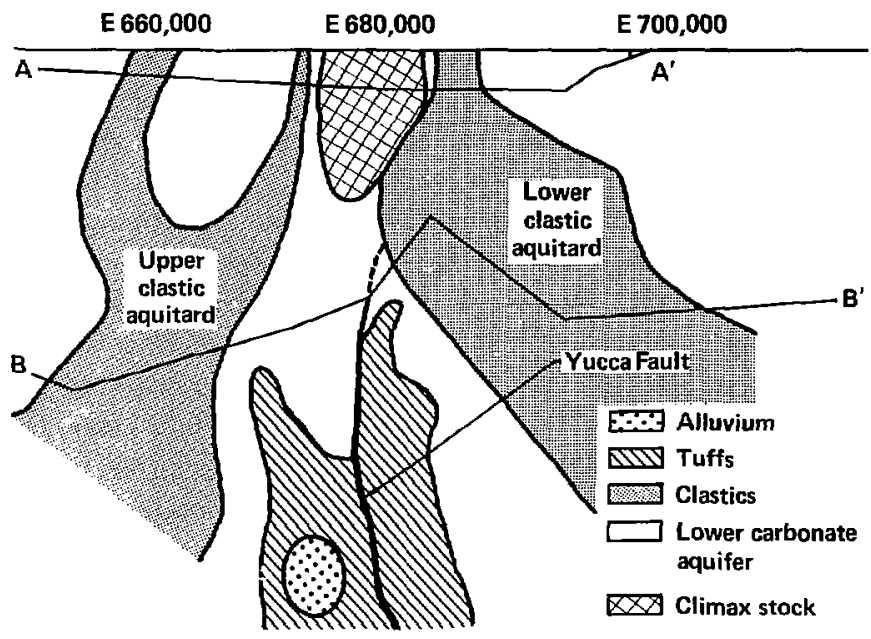

FIG. 23. Geology at $732 \mathrm{~m}$, ground surface at 1220-1830 $\mathrm{m}$ (from Winograd and Thordarson, 1975). 


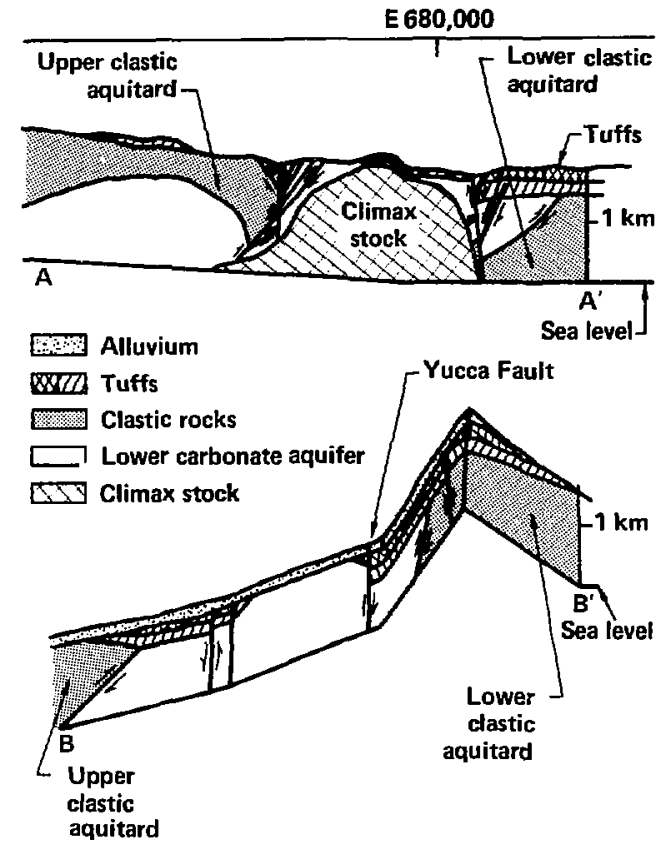

FIG. 24. Geologic sections whose locations are shown in Fig. 23 (from Winograd and Thordarson, 1975). 


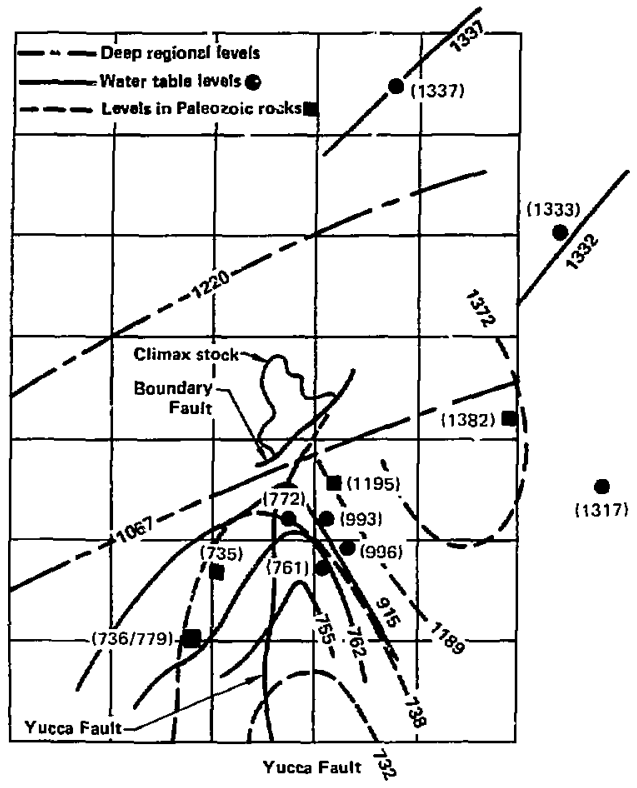

FIG. 25. Potentiometric levels in meters surrounding the $\mathrm{Cl}$ imax stock above MSL. Numbers in parentheses indicate measured water levels (where two numbers are separated by a slash, the first refers to the Paleozoic rocks; the second is the water table in the (enozoic rocks). 
Borehole investigations by the USGS were conducted from 1959-1961 to estimate the quantity of groundwater in the Climax stock (Walker, 1962). The location of these exploratory boreholes in the granite and the adjacent quartzite and limestone west of the stock are shown in Fig. 26. Table 1 summarizes total depth and water level in each borehole. Walker notes that the erratic and wide range of water levels suggests that no e;tensive zone of saturation exists within the stock at the levels tested. Furthermore, since none of these holes penetrated to the level of the regional water table, the locally occurring water is perched. This perched groundwater is thought to exist only in small zones where the rock is highly fractured, and is thought to result from infiltration due to precipitation on the ground surface in the immediate area.

In a summary of permeability tests conducted in the climax stock, Murray (1980) indicates that the bulk rock permeability can be highly variable. In moderately to highly fractured zones, the permeability values may 1 ie in the range of $10^{-4}$ to $10^{-1} \mathrm{D}$. On the other hand, the permeability of intact rock or healed fractures is found to be less than $10^{-9} \mathrm{D}$.

The underground workings (elev. $1120 \mathrm{~m} \mathrm{MSL}$ ) at the Pile Driver shaft are also above the reyional water table and almost devoid of groundwater with the exception of a few isolated seeps. These seeps may indicate the quantity of deep percolation recharging the regional flow. The geologic features of major hydraulic significance are the many shear zones and the fault, wibich was discovered while excavating drifts for the Spent Fuel Test. These features will have a major impact on the groundwater flow through the intercornected fracture system in the $\mathrm{Cl}$ imax stock. 


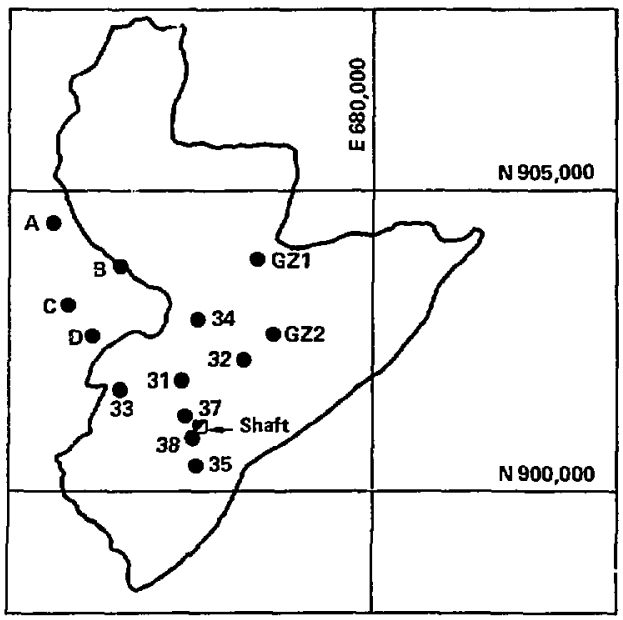

FIG. 26. Borehole locations in the Climax stock (see also Table 1). 
TABLE 1. Boreholiss in the Climax stock and vicinity.(a)

\begin{tabular}{|c|c|c|c|c|}
\hline $\begin{array}{l}\text { Borehole } \\
\text { (cf. Fig. 25) }\end{array}$ & $\begin{array}{l}\text { Ground } \\
\text { surface } \\
\text { elevation (b) } \\
\quad \text { (m) }\end{array}$ & $\begin{array}{l}\text { Hole } \\
\text { deptr } \\
\text { (m) }\end{array}$ & $\begin{array}{l}\text { Water } \\
\text { level(b) } \\
\text { (m) }\end{array}$ & Comments \\
\hline A & 1674 & 362 & 1387 & perched water \\
\hline B & 1599 & 60 & 1549 & perched water \\
\hline C & 1621 & 298 & 1475 & perched water \\
\hline 0 & 1588 & 115 & 1486 & percheo water \\
\hline 31 & 1559 & 366 & 1502 & perched water \\
\hline 32 & 1548 & 277 & 1418 & perched water \\
\hline 33 & 1571 & 301 & --- & dry \\
\hline 34 & 1571 & 301 & 1363 & perched water \\
\hline 35 & 1519 & 246 & 1494 & perched water \\
\hline 37 & 1543 & 508 & --- & dry \\
\hline 38 & 1536 & 610 & ---- & may be dry \\
\hline$G Z-1$ & 1590 & 549 & $-\cdots$ & unknown \\
\hline$G Z-2$ & 1550 & 549 & $-\cdots$ & unknown \\
\hline
\end{tabular}

(a) From Walker (1962) and Thordarson, et al. (1966).

(b) Referenced to MSL.

The crushed rock in the shear zones is highly permeable. This was determined qualitatively from infiltration tests conducted by pouring water directly on a shear zone. Typically, $200 \mathrm{ml}$ of water disappeared in less than a minute. Permeameter tests were conducted on samples from two of the shear zones (the same samples used in the grain size distribution determinations described earlier). Only material smaller than $1.25 \mathrm{~cm}$ was used. The crushed rock was initially placed into a water-filled permeameter; hence, the sample was in a loose state for initial tests. Subsequent tests were conducted after compacting the 
sample by striking the sides of the permeameter. Before final testing the water-saturated rock sample was allowed to stand for $18 \mathrm{~h}$. This gave the fine clay (which was in suspension) enough time to settle. Values of hydraulic conductivity ranged from $3 \times 10^{-3} \mathrm{~cm} / 5$ to $6 \times 10^{-2} \mathrm{~cm} / \mathrm{s}$ ( 3 to 60 darcies). The large value is typical for the loose, unconsolidated state, and the small vaiue is typical for the compacted state after settling $18 \mathrm{~h}$. The laboratory values cannot be construed to indicate values in situ, but do indicate the hydraulic nature of the material. The in situ value probably tends to be near the largest of the laboratory-determined values.

Depending on the extent and interconnectivity of the shear zones, highly permeable flow paths could exist throughout the $\mathrm{Climax}$ stock. Furthermore, the crushed rock of relatively large porosity in the shear zones would act as a storage reservoir, supplying water to discrete fractures in the stock.

In the hope of locating the regional water table within the Climax stock, one of the exploratory boreholes (UG-02) from the Spent Fuel Test was extended to $160 \mathrm{~m}$ below the present working level. After drilling to extend the borehole was concluded (September 25, 1980), a water level monitoring program was started. Table 1 summarizes the water level observations and a water level hydrograph for UG-02 is presented in Fig. 27. The hydrograph indicates that the water level (initially high due to excess drilling water) had stabilized by late November at about $974 \mathrm{~m} \mathrm{MSL}$ ( $14 \mathrm{~m}$ of water in the borehole). Bailer tests were conducted in February and March, 1981. Analyses of data from these tests indicate that the permeability is about $10^{-5} \mathrm{D}$.

It can be seen from the hydrograph (Fig. 27) that the water level in UG-02 is slowly rising (about $0.25 \mathrm{~m} / \mathrm{mo}$, November-May). The rising trend is perturbed by the bailer test events, but the water level rapidly recovers to the trend. This indicates that the borehole has intercepted an extensive area of saturated fractures that are being recharged. The observed recharge phenomenon may be part of the annual cyclic fluctuation that typically occurs in water table aquifers, and this may be the lacation of the regional water table within the Climax stock. Continued monitoring and additional boreholes are needed to determine if this, in fact, is the regional water table location. 


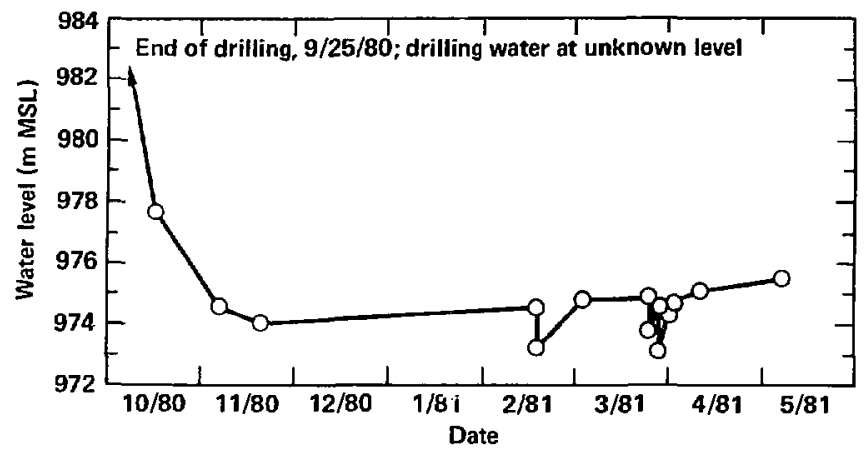

FIG. 27. Water level hydrograph for exploratory borehole UG-02. 
TABLE 2. Water leveis in exploratory borehole UG-02. a

\begin{tabular}{|c|c|c|c|}
\hline Date & Time & $\begin{array}{c}\text { Water } \\
\text { level } \\
\text { (m MSL) }\end{array}$ & Comments \\
\hline $09 / 25 / 80$ & -- & -- & Drilling ended \\
\hline $10 / 14 / 80$ & 1200 & 977.7 & \\
\hline $11 / 06 / 80$ & 1200 & 974.5 & \\
\hline $11 / 19 / 81$ & 1200 & 974.0 & \\
\hline $02 / 18 / 81$ & 1017 & 974.6 & \\
\hline $02 / 18 / 81$ & 1528 & 973.2 & Bailer Test \#1 \\
\hline $03 / 04 / 81$ & 1000 & 974.9 & \\
\hline $03 / 25 / 81$ & 1035 & 974.9 & \\
\hline $03 / 25 / 81$ & 1520 & 973.8 & Bailer Test \#2 \\
\hline $03 / 27 / 81$ & 1000 & 974.6 & \\
\hline $03 / 27 / 81$ & 1137 & 973.1 & Bailer Test \#3 \\
\hline $03 / 30 / 81$ & 0900 & 974.3 & \\
\hline $04 / 01 / 81$ & 1300 & 974.7 & \\
\hline $04 / 09 / 81$ & 1300 & 975.1 & \\
\hline $05 / 07 / 81$ & 1200 & 975.4 & $\begin{array}{l}\text { New probe on water } \\
\text { level indicator }\end{array}$ \\
\hline
\end{tabular}

INFERRING THE WATER TABLE LOCATION

Inferring the location of the water table within the climax stock depends on several factors: permeability of the granitic rock mass (with respect to the surrounding rock formations); quantity of recharge due to deep percolation from precipitation (with respect to the amount of underflow from north of NTS); and degree of fault inf luence when faults act as barriers or as flow conduits. 
Rock permeability can be placed in one of two broad categories -that of an aquifer or of an aquitard. As shown in Figs. 23 and 24, the Climax stock is bounded in a complicated manner by clastic aquitards and the carbonate aquifer. There is a dearth of boreholes in the Paleozoic rocks adjacent to the stock and, therefore, neither water levels nor permeability values are known. However, the fact that the hydraulic gradient is much steeper in iquitards than in aquifers can be used to qualitatively assess tne water table location.

Examples of the steep gradient in an aquitard (compared with the much flatter gradient in an adjacent aquifer) can be seen from water level data in the carbonate aquifer and surrounding clastic aquitards of Yucca Flat (see Figs. 20, 21, and 22). These differences in gradient indicate relative values of permeability in the aquitards and the aquifer. Furthermore, since the lower carbonate aquifer abuts the south end of the Climax stock (see $\mathrm{Fig} .22$ ), it is assumed that groundwater levels remain low here, even though they may rise sharply in the clastic rocks to the east and west.

The quantity of recharge through deep percolation of direct precipitation in the $\mathrm{Climax}$ stock area is important in determining the water table location within the stock. Perched ground water found in the stock has been attributed to vertical recharge from precipitation (Walker, 1962). Hence, there has been significant percolation to depths of several hundred meters.

The question then arises as to how much deep percolation has reached the regional water table. Water can certainly percolate to the regional water table if it has percolated to the perched locations. However, most of this precipitation infiltration may be intercepted by the perched aquifers, which could effectively block further deep percolation.

The isolated seeps in the underground workings at the $420-\mathrm{m}$ level may be indicative of the amount of deep percolation that is not intercepted by or is overflow from perched water locations. If it is indicative, a crude estimate of the quantity of deep percolation (at least below tho $420-\mathrm{m}$ level) could be made by performing an inventory of 
the seeps along the roof area of the underground workings, and by monitoring evaporative transport due to the ventilation system. This could also be turned into a crude estimate of rock saturation at the present working level.

The influence of faults on the groundwater flow system near the Climax stock may be a very important consideration. As can be seen from Fig. 24, the fault pattern around the stock is complex. To assess the influence of faults, their nature must be carefully investigated. This is of ten best inferred from water level measurements. However, the area's dearth of boreholes for water level measurements precludes this type of assessment at the present time. Figure 22 gives some indication that Yucca fault could be a flow barrier. However, this effect is masked because of the presence of the clastic aquitird. The sharp drop in water level from east to west into Yucca flat could be caused by Yucca Fault as well as by the low-permeability clastic rocks.

The fault that runs through the north end of the Spent fuel Test drifts (see Figs. 17 and 18) would behave as a flow barrier because of its wide zone of clay gouge. If this fault continues entirely through the Climax stock and if its composition remains similar to that encountered in the Spent Fuel Test workings, it would certainly form an effective barrier to flow from north to south through the stock. Hence, the groundwater flow would tend to detour around the stock, and there would probably be an abrupt drop in water table elevation across the fault.

Based on the geologic and hydrologic information available, the following inferences are made:

1. The trough in the water table, which runs along the length of Yucca Flat, probably continues to the north, past the Climax stock, because of flow throligh the relatively high-permeability carbonate aquifer that travels continuously from the north to the south around the west side of the Climax stock (see Figs. 23 and 24).

2. The north-south hydraulic gradient in the carbonate aquifer on the west side of the stock may be fairly steep since the available cross-sectional flow area is smal1. However, the extensive faulting here (see Fig. 24) may counteract this area-reduction effect by increasing overall rock permeability. 
3. On the east side of the Climax stock the lower clastic aquitard blocks north-south flow and keeps water levels high.

4. Groundwater flow through the stock probably moves from the northeast toward the southwest in response to water levels in the surrounding rocks (which are high to the northeast and lower to the southwest).

5. If the shear zones in the stock are extensive and interconnected, the bulk rock mass will appear to be highly permeable and, consequently, the water table will be relatively flat throughout the stock. However, if the fault encountered in the Spent Fuel Test workings is extensive and filled with clay gouge throughout, there would be an abrupt change in water level across the fault.

6. Water table elevations within the climax stock may lie from $1100-1200 \mathrm{~m}$ in the northeast to $800-900 \mathrm{~m}$ in the southwest. These water levels were chosen as reasonable possibilities, based on extensions from known water levels, the surrounding geology, and the assumption that the regional water table must be no higher than about $975 \mathrm{~m}$ at the Spent fuel Test location (in borehole UG-02). However, if (as postulated in item 5 above) the bulk permeability of the stock is large, the water table may remain lower in the northeast. This would induce a very steep gradient in the lower clastic rocks adjacent to the stock in the northeast.

\section{CONCLUSIONS}

The water tabie location in the climax stock granitic intrusive, and the degree of saturation of the rock at the present working level $(1120 \mathrm{~m}$ MSL) have not been definitively determined. However, it has been suggested (based on analysis of known geological and hydrological data) that the water table elevation in the stock may slope down from about $1100-1200 \mathrm{~m}$ in the northeast to $800-900 \mathrm{~m}$ in the southwest; and that it may lie at an elevation of $975 \mathrm{~m}$ MSL beneath the location of the Spent Fuel Test. It has also been suggested that the degree of saturation may 
be approximated by a detailed inventory of isolated seeps to the underground workings along with monitoring of moisture transport via the ventilation system.

More definitive conclusions regarding the hydrologic regime in the Climax stock can only be supplied through a carefully planned investigatory program. A water budget would be required to determine the source of water deep within the stock, and to help establish the degree of saturation of the unsaturated rocks above the water table. Deep wells would be needed in the Paleozoic rocks adjacent to the granitic-intrusive mass to determine water table elevations surrounding the stock. These elevations would provide the boundary conditions for water levels and water movement within the stock. Finally, boreholes would have to be drilled within the Climax stock to determine not only the location of the water table, but also the influence of shear zones, faults, and discrete fractures on groundwater flow through the stock.

\section{ACKNOWLEQGMENTS}

The author wishes to express his appreciation to Carlos Vivoni for the valuable assistance rendered in both field and laboratory investigations conducted for this report. 
All ingham, J. S., and I. Zietz, Geophysical Data on the Climax Stock Nevada Test Site, Nye County, Nevada, USGS TEI-794, U.S. Geological Survey, Denver, Colo. (1961).

Barries, H., F. N. Houser, and F. G. Poole, Geologic Map of the Oak Spring Quadrangle, Nye Co., Nevada, USGS Quad, Map GQ-214, U.S. Geological Survey, Denver, Colo. (1963).

Borg, I. Y., Survey of Piledriver Results and Preliminary Interpretation of Three Postshot Cores in and Near the Cavity, Lawrence Livermore National Laboratory, Livermore, Calif., UCRL-50865 (1970).

Borg, I. Y., R. Stone, H. B. Levy, and L. D. Ramspott, Information Pertinent to the Migration of Radionuclides in Ground Water at the Nevada Test Site, Lawrence Livermore National Laboratory, Livermore, Calif., UCRL-52078 Part 1 (1976).

DOE, Safety Assessment Document for the Spent Reactor Fuel Geologic Storage Test in the Climax Granite Stock at the Nevada Test Site, U.S. Department of Energy, Nevada Operations Office, Las Vegas (1980).

Ege, J. R., and R. E. Davis, Preliminary Appraisal of Proposed Tiny Tot Site \#2 and Exploratory Dril1 Hole Ue15f, Area 14, Nevada Test Site, USGS Technical Letter: Area 15-6, U.S. Geological Survey, Denver, Colo. (May 5, 1965).

Heuze, F. E., The Climax Granite, Nevada Test Site, as a Host for a Rock Mechanics Test Facility, Related to Geologic Disposal of High Level Nuclear Waste, Lawrence Livermore National Laboratory, Livermore, Calif., UCID 18946 (1981).

Houser, F. N. and F. G. Poole, Preliminary Geologic Map of the Climax

Stock and Vicinity - Nye County, Nevada, Miscellaneous Geologic Investigations, Map I-328, U.S. Geological Survey, Denver, Colo. (1960).

Isherwood, D. J., E. Raber, D. G. Coles, and R. Stone, Program Plan: Field Radionuclide Migration Studies in Climax Granite, Lawrence Livermore National Laboratory, Livermore, Calif., UCID 18838 (1980). 
Maldonado, F., Summary of GeoTogy and Physical Properties of the Climax

Stock. Nevada Test Site, USGS Open-File Report 77-356, U.S. Geological Survey, Denver, Colo. (1977).

Mifflin, M. D., Delineation of Ground Water Flow Systems in Nevada,

Technical Report Series $H-W$, Hydrology and Water Resources,

Publication No. 4, Desert Research Institute, Reno, Nev., (1968). Murray, W. A., Permeability Testing of Fractures in Climax Stock Granite,

NTS, Repository Sealing Field Testing Workshop 1980, Santa Fe, N.M.,

DOE Office of Nuclear Waste Isolation (Sept. 18-19. 1980); also

Lawrence Livermore National Laboratory, Livermore, Calif.,

UCRL-85231 Preprint (7980).

Ramspott, L. D., L. B. Ballou, R. C. Carlson, D. N. Montan, T. R.

Butkovich, J. E. Duncan, W. C. Patrick, D. G. Wilder, W. G. Brough

and M. C. Mayr, Technical Concept for a Test of Geologic Storage of

Spent Reactor Fuel in the Climax Granite, Nevada Test Site, Lawrence

Livermore National Laboratory, Livermore, Calif., UCRL-52796 (1979). Ramspott, L. D., and N. W. Howard, Average Properties of Nuclear Test

Areas and Media at the USERDA Nevada Test Site, Lawrence Livermore

National Laboratory, Livermore, Calif., UCRL-51948 (1975).

Thordarson, W., R. A. Young, and I. J. Winograd, Records of Wells and

Test Holes in the Nevada Test Site and Vicinity (through December

1966), USGS Report TEI-872 (1967).

USGS, Field Trip to Nevada Test Site, Open-File Report 76-313, U.S.

Geological Survey, Denver, Colo. (1976).

Walker, G.E., Ground Water in the Climax Stock, Nevada Test Site, Nye

County, Nevada, USGS TEI-813, U.S. Geological Survery, Denver, Colo. (1962).

Winograd, I. J. and W. Thordarson, Structural Control of Ground-Water

Movement in Miogeosync 7 inal Rocks of South-Central Nevada, in

Ecke1, E. B., ed., Nevada Test Site: Geol. Soc. America Mem. 110,

p. $35-48$ (7968).

Winograd, I. J., and W. Thordarson, Hydrogeologic and Hydrochemical

Framework, South-Central Great Basin, Nevada-California, with

Special Reference to the Nevada Test Site, USGS Professional paper

712-C, U.S. Geological Survey, Denver, Colo. (1975). 
Wilder, D. G., Fault Thru Receiving Room, SFT-C, Memorandum No. EG 79-19, Earth Sciences Division, Lawrence Livermore National Laboratory, Livermore, Calif. (Aug. 20, 1979).

Wilder, D. G., and W. C. Patrick, Geotechnical Status Report for Test Storage of Spent Reactor Fuel in Climax Granite, Nevada Test Site, Lawrence Livermore National Laboratory, Livermore, Calif., UCRL-85096 (1980). 